\title{
接合面に山形加工を施した集成材モーメント抵抗接合部の力学特性評価 MECHANICAL PROPERTY EVALUATION OF WOODEN MOMENT RESISTING JOINTS WITH SERRATED SURFACE
}

\author{
井戸田 秀樹* \\ Hideki IDOTA
}

\begin{abstract}
The purpose of this paper is to evaluate the mechanical properties of wooden moment resisting joints with serrated surface. In order to evaluate the basic characteristics of the joints with serrated surface, this paper proposes the mechanical models which can describe stiffness, yield strength, maximum strength and maximum deformations for shearing behavior of the serrated surface joints. The proposed model is verified with the shearing test results considering the pitch and slope angle of serration. Based on the proposed mechanical model, the loaddeformation relationship of the proposed moment resisting joints with serrated surface is presented and verified with the test results. The results obtained in this paper are as follows:
\end{abstract}

1) Stiffness, yield strength and maximum strength of shearing joints with serrated surface can be evaluated by Eq.(8), (9) and (13).

2) Load-deformation relationship of the moment resisting joints with serrated surface can be described with Eq.(21).

3) The results evaluated by the proposed mechanical models agree well with the test results.

Keywords : glue laminated wood, moment resisting joint, serrated surface, moment resisting frame 集成材，モーメント抵抗接合，山形加工，木質ラーメン

\section{1。序}

高い施工性を兼亦備えた高性能モーメント抵抗接合部として, 筆 者は接合面に山形加工を施した集成材の柱はり接合部（以降，山形 モーメント抵抗接合部と呼ぶ）を提案した ${ }^{5}$. この接合部は，図 1 に 示すように, 柱はりともに接合せん断面に連続した山形加工を施し, それらの山がお互いに噛み合うように合わせたのち，ボルトにて柱 はりを締め付けるものである，接合面に生じたせん断力は山の側面 を介して広い面積で伝達されるため高い耐力が期待でき，またボル トやシアコネクタのようにクリアランスによる初期の剛性低下が全 くないのが特徴である，組み立ては接合面に山形加工を施した部材 をボルトで締め付けるだけであり, 従来のボルト接合と同様の極め て簡単な施工でモーメント抵抗接合部が形成できる.

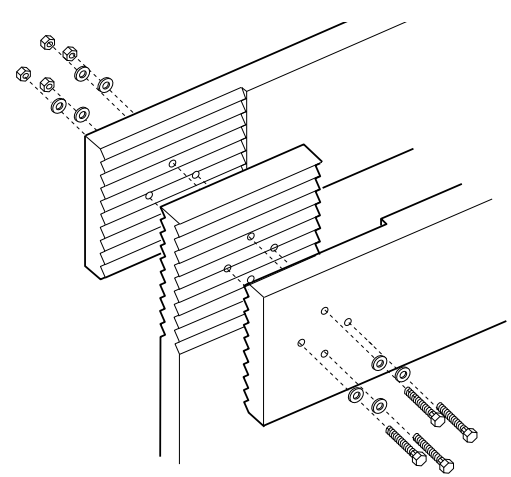

図 1 山形加工モーメント抵抗接合部
本論文は，提案する接合部のモーメント抵抗メカニズムを把握す るとともに, その力学的モデルを提案し, それに基づいてモーメン 卜抵抗接合部の荷重変形関係の評価法を提示するものである.

\section{2. 山形接合部の 2 面せん断実験}

山形モーメント抵抗接合部では，噛み合った山斜面どうしの支圧 によって応力を伝達する。 また，山斜面に生じた反力は柱とはりの 接合面を開く作用を生じさせ，締め付けているボルトの軸力と釣り 合う。したがって, 本接合部の力学的な挙動を把握するためには, まず接合面に対するせん断実験を行い，その挙動を説明する必要が ある、そこで本研究では，山形モーメント抵抗接合部に対する基礎 実験として，まず山形加工を施した接合部の 2 面せん断実験を行い, そのせん断挙動の定量的評価を行つた.

\subsection{2 面せん断実験の概要}

試験体の一覧および試験体形状を表 1 および図 2 に示す。試験体 は，主材を 2 枚の側材で挟み，径 $12 \mathrm{~mm}$ のボルト 1 本を接合面内に 配置した 2 面せん断型の試験体である. 主材および側材にはラミナ 厚 $32 \mathrm{~mm}$, 曲げヤング係数 $11.2 \sim 12.2 \mathrm{kN} / \mathrm{mm}^{2} \quad(110.0 \sim 124.8 \mathrm{t} /$ $\left.\mathrm{cm}^{2}\right)$ の同一等級ベイマツ集成材を用いた。 また, 側材の足元には, 載荷時に側材の開きを拘束する径 $12 \mathrm{~mm}$ のボルト 2 本を配置した.

実験パラメータは, 山形加工の有無, 山斜面の角度 $\theta$, 山ピッチ $p$, ボルトの座金径 $d$ である. 山加工形状を図 3 に示す．山形加工のな い F シリーズ試験体は比較のために用意した基本試験体であり，座 
金径 $d$ が $25 \mathrm{~mm}, 36 \mathrm{~mm}, 48 \mathrm{~mm}$ の 3 タイプのボルトを用いた．座 金の厚さはすべて $2.0 \mathrm{~mm}$ である。山形加工を施した $\mathrm{S}$ シリーズ試験 体は, 山斜面の角度 $\theta$ について $30^{\circ}, 45^{\circ} の 2$ タイプ, 山ピッチ $p$ に ついて $12.5 \mathrm{~mm}, 20 \mathrm{~mm}, 25 \mathrm{~mm}$ の 3 タイプ, ボルト座金径 $d$ につ いて $25 \mathrm{~mm}, 36 \mathrm{~mm}, 48 \mathrm{~mm}$ の 3 タイプを計画した。試験体数は原 則として各パラメータに対して 3 体ずつである.

載荷は，試験体を圧縮試験機上に設置し，主材の上部を試験機で 直接押すことにより行った。変位は試験体の主材・側材のボルト高 さ側面両側に取り付けた変位計によりそれぞれの鉛直方向変位を測 定し, 主材の平均変位から側材の平均変位を差し引いたものを主材 と側材間の相対変位とした。

\subsection{2 面せん断実験の結果および考察}

各試験体の荷重 - 変形関係を図 4 に示す。通常のボルト接合部で ある F シリーズの試験体では，ボルト穴のクリアランスによるわず かな滑りが生じた後，剛性を低下させながら緩やかな耐力上昇が続 いた。一方，接合表面に山形加工を施した接合部である $\mathrm{S}$ シリーズ では，ボルト接合部に比べると初期滑りはなく，高い初期剛性と最 大耐力を示した。 山斜面の角度 $\theta$ が $30^{\circ}$ の試験体（S12-30, S20-30, S25-30 の各シリーズ）では，主材と側材の相対変位 $\delta$ が山ピッチ $p$ の半分弱のときに耐力の極大值が観測され，その後一旦耐力は低下 するが再び上昇し，最初に観測された耐力の極大值を上回った。こ れは，すべり変形によって山の頂点どうしが揃う直前付近で一度極 大值が発生し，その後頂点を超えると耐力は減少するが，次に隣の 山斜面と再び接触することで再度せん断抵抗が生ずるためである。一 方, $\theta=45^{\circ}$ の試験体では山のすべりが少なく, 主材と側材の山の頂上 ぞうしが揃う前に最大耐力が発生し，その後側材が面外曲げ変形を 伴って主材から離れ始女, 耐力が急激に減少した。

\section{3. 山形接合部のせん断剛性およびせん断耐力評価}

\section{1 山形接合面の耐力特性}

本試験体のせん断耐力は，噛み合った山斜面の支圧抵抗と，側材 を挟むためのボルトの 2 面せん断抵抗の両方が足し合わされたもの と考えることができる，そこで，山斜面の支圧抵抗だけを検討する ため, 図 5 に示すように山形試験体 S シリーズの耐力から従来型の

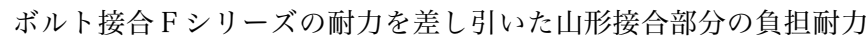
のみを対象に評価を行う，Fシリーズの耐力は，各座金径の荷重変形 曲線をトリリニアモデルに置換し，それを 3 体ごとに平均すること で求めた，Fシリーズ試験体のトリリニアモデルのパラメータである 初期剛性 $K_{1}$, 降伏耐力 $P_{y}$, 降伏変位 $\delta_{y}$, 二次剛性 $K_{2}$, 終局耐力 $P_{u}$, 終局耐力到達時の変形量 $\delta_{y 2}$ は表 2 に示す通りである.

このパラメータに基づいたボルト分の負担荷重を実験結果から差 し引いたときの荷重変形関係の一例を図 6 に示す。最大耐力近傍ま での荷重変形関係を見ると，比較的明瞭な弾性範囲があり，その後 塑性化とともに剛性が低下して最大耐力を迎え，以降大きな塑性変 形とともに耐力が低下していった．本研究では，この山形加工部分 のみのせん断挙動について力学的な特性の評価を行う.

評価にあたっては荷重変形関係の特徵を考慮し，図 7 に示すよう に, ボルトの負担耐力を減じた荷重変形曲線から降伏点（降伏耐力 $P_{y}$, 降伏変位 $\delta_{y}$ ), 最大耐力点 (最大耐力 $P_{\text {max }}$, 最大耐力時の変位 $\left.\delta_{\text {max }}\right)$ の 2 点を，それぞれの点を結んだ直線が荷重変形曲線と対応す
表 12 面せん断試験体一覧

\begin{tabular}{|c|c|c|c|c|c|c|}
\hline 試験体名 & 山形加工の有無 & $\begin{array}{c}\text { 瞇み合わせる } \\
\text { 山の数 } \\
n\end{array}$ & $\begin{array}{l}\text { 山ピッチ } \\
p(\mathrm{~mm})\end{array}$ & $\begin{array}{l}\text { 山角度 } \\
\theta \text { (deg) }\end{array}$ & $\begin{array}{l}\text { 座金径 } \\
d(\mathrm{~mm})\end{array}$ & 試騟体数 \\
\hline $\begin{array}{l}\text { F-W25 } \\
\text { F-W36 } \\
\text { F-W48 }\end{array}$ & $x$ & - & - & - & $\begin{array}{l}25 \\
36 \\
48\end{array}$ & \multirow{7}{*}{3} \\
\hline $\begin{array}{l}\text { S12-30-W25 } \\
\text { S12-30-W36 } \\
\text { S12-30-W48 }\end{array}$ & \multirow{6}{*}{0} & \multirow{6}{*}{4} & 12.5 & \multirow{4}{*}{30} & $\begin{array}{l}25 \\
36 \\
48\end{array}$ & \\
\hline S20-30-W25 & & & & & 25 & \\
\hline $\begin{array}{l}\text { S20-30-W36 } \\
\text { S20-30-W48 }\end{array}$ & & & 20.0 & & $\begin{array}{l}36 \\
48\end{array}$ & \\
\hline $\begin{array}{l}\text { S25-30-W25 } \\
\text { S25-30-W36 } \\
\text { S25-30-W48 }\end{array}$ & & & 25.0 & & $\begin{array}{l}25 \\
36 \\
48\end{array}$ & \\
\hline $\begin{array}{l}\text { S12-45-W25 } \\
\text { S12-45-W36 }\end{array}$ & & & 12.5 & \multirow[b]{2}{*}{45} & $\begin{array}{l}25 \\
36 \\
48\end{array}$ & \\
\hline $\begin{array}{l}\text { S12-45-W48 } \\
\text { S25-45-W25 } \\
\text { S25-45-W36 } \\
\text { S25-45-W48 }\end{array}$ & & & 25.0 & & $\begin{array}{l}25 \\
36 \\
48\end{array}$ & \\
\hline
\end{tabular}

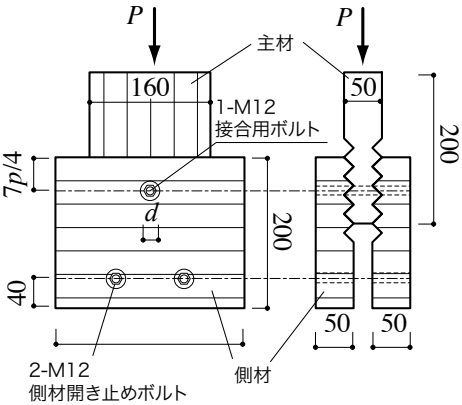

図2 2 面せん断試験体

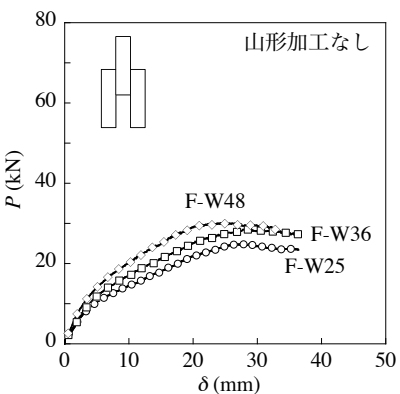

(a) F シリーズ

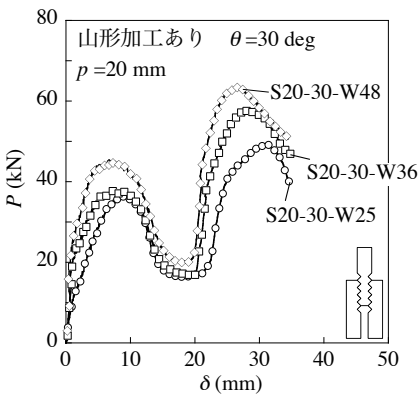

(c) S20-30 シリーズ

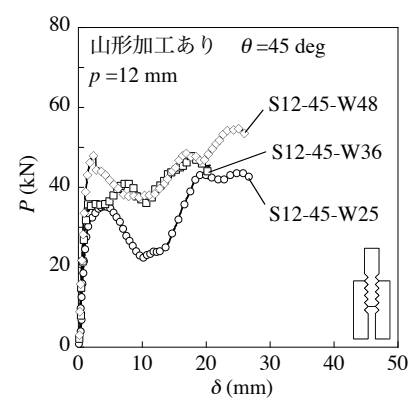

(e) S12-45 シリーズ

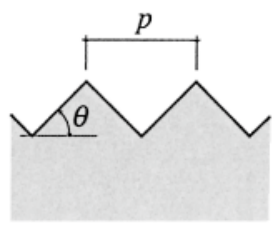

図 3 山加工詳細

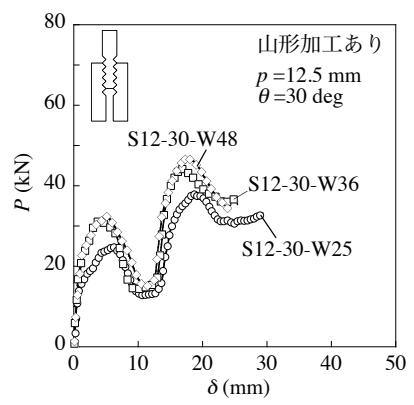

(b) S12-30 シリーズ

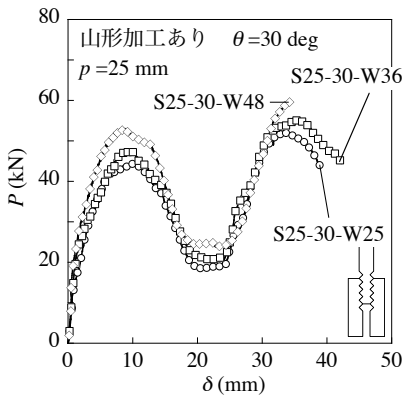

(d) S25-30 シリーズ

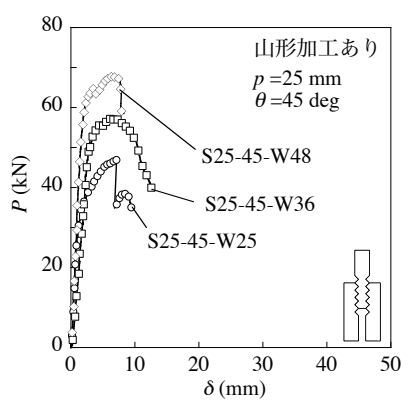

(f) S25-45 シリーズ
図42面せん断実験の荷重変形関係 
るように読み取ったままた，この 2 点を用い，原点と降伏点を結ぶ 直線の傾きを一次剛性 $K_{1}$, 降伏点と最大耐力点を結ぶ直線の傾きを 二次剛性 $K_{2}$ と定義した。

こうして定義した各特性值を試験体ごとに表 3 に示す， $P_{y}, K_{1}$ の 各特性は, 座金径 $d$ および山斜面の角度 $\theta$ が大きいほど高い值を示 したが，山ピッチ $p$ の影響は観察されなかった。また， $K_{2}$ は $p$ と $\theta$ の影響を大きく受けるが， $d$ との高い相関は見られなかった。一方, $P_{\text {max }}$ は $p, d, \theta$ いずれに対しても比例関係が認められた。

\section{2 山形接合面の力学モデル}

前節で観察した特性を説明するため, 山形接合部の力学モデルに ついて考える. 図 8 に示すように，山形接合面がせん断力を受けた 場合，山斜面に沿った滑りおよび支圧による山斜面のめり込みが生 じる. 山斜面に沿った滑りにより生ずる摩擦力, および山斜面のめ り込み反力は，側材の開きを拘束するボルト座金の側材へのめり込 み力と釣り合うことになる。そこで，図 9 に示すように片側の山斜 面における力の釣り合いをボルト座金のめり込み反力 $R_{b}$ と山斜面の めり込み反力の合力 $R_{s}$ を用いて考える.このとき, 側材に作用する $x$, $y$ 各方向の力の釣り合いは,

$$
\begin{aligned}
& R_{b}-n R_{s} \cos \theta+\mu n R_{s} \sin \theta=0 \\
& -n R_{s} \sin \theta-\mu n R_{s} \cos \theta+Q=0
\end{aligned}
$$

となる.ここに, $\mu$ :木材どうしの摩擦係数, $n$ : 噛み合っている山の数, $\theta$ : 山の傾斜角, $Q: 1 つ$ つん断面に作用するせん断力であり, 2 章の 2 面せん断実験の荷重 $P$ との関係は $Q=P / 2$ である. いま, 主 材と側材の $x, y$ 方向相対変位を $\delta_{x}, \delta_{y}$, 山斜面方向および垂直方向 の変位を $\delta_{s}, \delta_{t}$ とすると, 変形の適合条件から,

$$
\begin{aligned}
& \delta_{x}=\delta_{s} \sin \theta-\delta_{t} \cos \theta \\
& \delta_{y}=\delta_{s} \cos \theta+\delta_{t} \sin \theta
\end{aligned}
$$

が成り立つ. また, $R_{b}$ と $R_{s}$ はボルト座金のめり込み一次剛性 $k_{b 1}$, お よび山斜面のめり込み一次剛性 $k_{s 1}$ を用いて,

$$
\begin{aligned}
& R_{b}=k_{b 1} \delta_{x} \\
& R_{s}=k_{s 1} \delta_{t}
\end{aligned}
$$

と表すことができる.（1）〜（6）式から $Q$ と $\delta_{y}$ の関係を導くと,

$$
\begin{aligned}
& Q=K_{1} \delta_{y} \\
& K_{1}=\frac{n k_{b 1} k_{s 1} \sin \theta(\sin \theta+\mu \cos \theta)}{k_{b 1}-n k_{s 1} \cos \theta(\mu \sin \theta-\cos \theta)}
\end{aligned}
$$

となる.ここに $K_{1}$ は山形接合面のせん断挙動に対する一次剛性である. ボルトが一般的な形状だとすれば，接合部の降伏は， $R_{b}$ あるいは $R_{s}$ のいずれかが降伏強度に達したときに生ずる，従って，接合部の

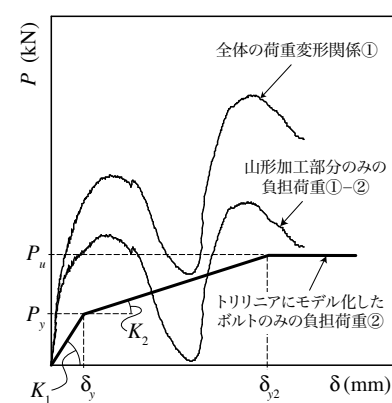

図 5 山形部分耐力の評価方法

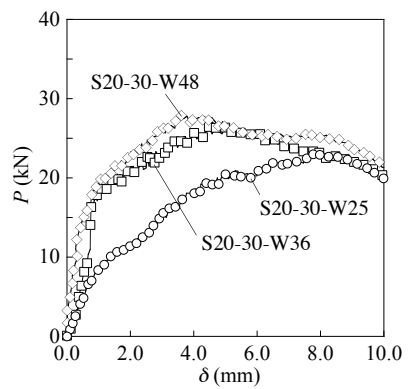

(a) S20-30 シリーズ試験体
表2Ｆシリーズ試験体のトリリニア モデルパラメータ

\begin{tabular}{c|c|c|c}
\hline Specimen & F-W25 & F-W36 & F-W48 \\
\hline$K_{1}(\mathrm{kN} / \mathrm{mm})$ & 1.99 & 1.88 & 2.69 \\
\hline$P_{y}(\mathrm{kN})$ & 11.4 & 14.1 & 15.0 \\
\hline$\delta_{y}(\mathrm{~mm})$ & 5.72 & 7.56 & 5.58 \\
\hline$K_{2}(\mathrm{kN} / \mathrm{mm})$ & 0.80 & 0.89 & 0.88 \\
\hline$P_{u}(\mathrm{kN})$ & 25.1 & 29.9 & 28.5 \\
\hline$\delta_{y_{2}}(\mathrm{~mm})$ & 22.8 & 25.3 & 20.8 \\
\hline \multicolumn{2}{|l}{}
\end{tabular}

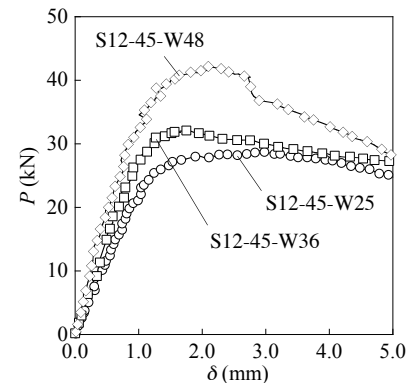

(b) S12-45 シリーズ試験体
図 6 山形部分のみの負担荷重と変形の関係

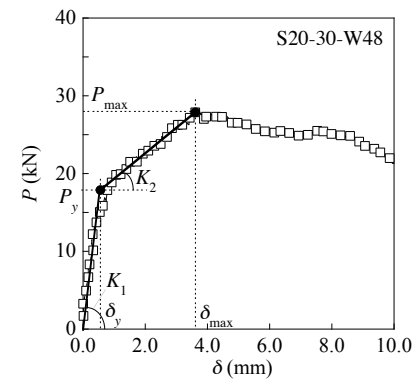

(a) S20-30-W48 の一例

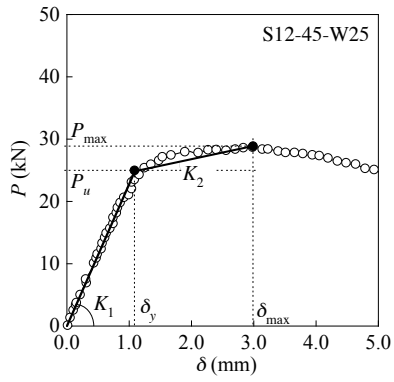

(b) S12-45-W25 の一例
図 7 荷重変形曲線と特性值

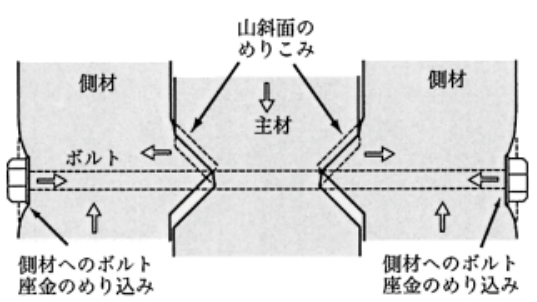

図8 山形加工部分の抵抗メカニズム

表 3 荷重変形関係の特性値一覧

\begin{tabular}{c|c|c|c|c|c|c|c}
\hline 試験体名 & $P_{y}(\mathrm{kN})$ & $\delta_{y}(\mathrm{~mm})$ & $K_{1}(\mathrm{kN} / \mathrm{mm})$ & $P_{\max }(\mathrm{kN})$ & $\delta_{\max }(\mathrm{mm})$ & $K_{2}(\mathrm{kN} / \mathrm{mm})$ & $K_{2} / K_{1}$ \\
\hline S12-30-W25 & 10.7 & 0.75 & 14.3 & 15.4 & 4.07 & 1.42 & 0.10 \\
\hline S12-30-W36 & 16.9 & 0.90 & 18.8 & 22.0 & 3.69 & 1.83 & 0.10 \\
\hline S12-30-W48 & 17.8 & 0.83 & 21.4 & 22.5 & 3.30 & 1.90 & 0.09 \\
\hline S20-30-W25 & 8.8 & 0.66 & 13.3 & 22.1 & 6.87 & 2.14 & 0.16 \\
\hline S20-30-W36 & 18.2 & 1.14 & 16.0 & 30.4 & 5.80 & 2.62 & 0.16 \\
\hline S20-30-W48 & 19.3 & 0.87 & 22.2 & 28.7 & 5.60 & 1.99 & 0.09 \\
\hline S25-30-W25 & 10.0 & 0.78 & 12.9 & 27.0 & 7.30 & 2.61 & 0.20 \\
\hline S25-30-W36 & 16.7 & 0.92 & 18.1 & 32.4 & 7.61 & 2.35 & 0.13 \\
\hline S25-30-W48 & 17.9 & 0.90 & 20.0 & 33.2 & 7.48 & 2.32 & 0.12 \\
\hline S12-45-W25 & 25.1 & 0.87 & 29.0 & 31.0 & 1.90 & 5.71 & 0.20 \\
\hline S12-45-W36 & 28.0 & 0.87 & 32.1 & 33.1 & 1.40 & 9.49 & 0.30 \\
\hline S12-45-W48 & 30.2 & 0.79 & 38.2 & 34.2 & 1.38 & 6.44 & 0.17 \\
\hline S25-45-W25 & 24.0 & 0.85 & 28.3 & 34.0 & 4.00 & 3.17 & 0.11 \\
\hline S25-45-W36 & 32.0 & 0.87 & 36.8 & 48.2 & 3.20 & 6.87 & 0.19 \\
\hline S25-45-W48 & 37.5 & 0.89 & 41.9 & 52.1 & 2.80 & 7.61 & 0.18 \\
\hline
\end{tabular}


降伏せん断耐力 $Q_{v}$ を次式で定義する.

$$
Q_{y}=\min \left(Q_{b}, Q_{s}\right)
$$

ここに, $Q_{b}: R_{b}$ がボルト座金のめり込みの降伏耐力 $R_{b y}$ に達するとき の作用せん断力, $Q_{s}: R_{s}$ が山斜面のめり込みの降伏耐力 $R_{s y}$ に達する ときの作用せん断力である， $Q_{b}$ および $Q_{s}$ は次式で表される.

$$
\begin{aligned}
& Q_{b}=R_{b y} \frac{\sin \theta+\mu \cos \theta}{\cos \theta-\mu \sin \theta} \\
& Q_{s}=n R_{s y}(\sin \theta+\mu \cos \theta)
\end{aligned}
$$

降伏後の剛性 $K_{2}$ は, 先に降伏した要素の二次剛性に依存すると考 え，(8）式を考慮し次式で求められるものとする.

$$
K_{2}= \begin{cases}\frac{n k_{b 2} k_{s 1} \sin \theta(\sin \theta+\mu \cos \theta)}{k_{b 2}-n k_{s 1} \cos \theta(\mu \sin \theta-\cos \theta)} & \left(Q_{b}<Q_{s} \text { のとき }\right) \\ \frac{n k_{b 1} k_{s 2} \sin \theta(\sin \theta+\mu \cos \theta)}{k_{b 1}-n k_{s 2} \cos \theta(\mu \sin \theta-\cos \theta)} & \left(Q_{b}>Q_{s} \text { のとき }\right)\end{cases}
$$

ここに, $k_{b 2}$ : ボルト座金のめり込み二次剛性, $k_{s 2}$ : 山斜面のめり込 み二次剛性である。

最大耐力 $Q_{\text {max }}$ は, (8), (9) および（12）式で求めた一次剛性 $K_{1}$, 降伏耐力 $Q_{y}$, 二次剛性 $K_{2}$ を用い, 次式のように算出する.

$$
Q_{\text {max }}=Q_{y}+K_{2}\left(\delta_{\max }-\frac{Q_{y}}{K_{1}}\right)
$$

ここに, $\delta_{\text {max }}$ は最大耐力時のせん断変形量である. $\delta_{\text {max }}$ は山形接合部 がせん断抵抗するしくみと山斜面の反力を考慮し，以下のように考 えて評価した。

まず，せん断力を受ける山形接合部は図 9 で示したように山斜面 に沿った主材と側材のすべり，およびボルト座金と山斜面のめり込 みによってせん断変形量が決まる. いま, 山斜面に生ずる反力 $R_{s} に$ よって山斜面はめり込んだりせず山形状は変化しないと仮定する. このとき, 最大耐力は主材と側材の山頂部が一致したとき,すなわち, せん断変形が $p / 2$ のきに発生することになる。ところが実際には山 斜面のめり込みやそれに伴う山頂のつぶれが生じるため, 変形が $p / 2$ に達する前に耐力は低下する。 そこで, 最大耐力発生時の変形量 $\delta_{\text {max }}$ は山斜面に生じる反力 $R_{s}$ が大きいほど小さくなることを考慮し， $\delta_{\max }$ と $R_{s}$ の間に次式のような関係を仮定する.

$$
\frac{\delta_{\max }}{p / 2}+\frac{R_{s}}{R_{s 0}}=1
$$

ここに， $R_{s 0}$ はせん断面がすべり変形を生じずに最大耐力を迎えると 仮定したときの見かけ上の山斜面反力である。（11）式および，

$$
Q_{s 0}=n R_{s 0}(\sin \theta+\mu \cos \theta)
$$

の関係を用いることで，(14）式は次式のように書ける.

$$
\frac{\delta_{\max }}{p / 2}+\frac{Q_{s}}{Q_{s 0}}=1
$$

$Q_{s 0}$ は山斜面に見かけ上の反力 $R_{50}$ が生じるときの作用せん断力であ る. 図 10 は，降伏点および二次剛性から決まる荷重変形関係の座標 上に（16）式を併せて示したものである，(16）式は，最大耐力発生 時のせん断変形量と作用せん断力との関係を示したものであるから, 荷重変形関係と (16) 式の交点の横軸上の座標が $\delta_{\text {max }}$ となる. したがつ て， $\delta_{\max }$ は次式のように求められる.

$$
\delta_{\max }=\frac{p Q_{y}\left(K_{2} / K_{1}-1\right)+n R_{s 0} p(\sin \theta+\mu \cos \theta)}{2 n R_{s 0}(\sin \theta+\mu \cos \theta)+K_{2} p}
$$

ただし, $\delta_{\text {max }}>\delta_{y}$ である. (14) 式の仮定の妥当性は 3.4 節で検証する.

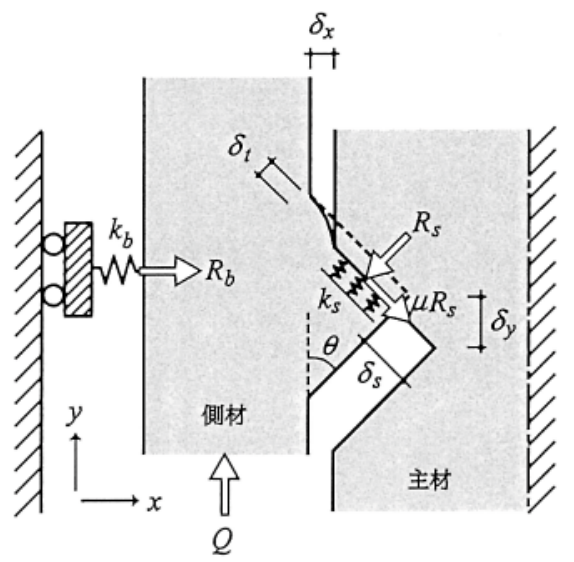

図 9 側材に作用する力の釣り合い

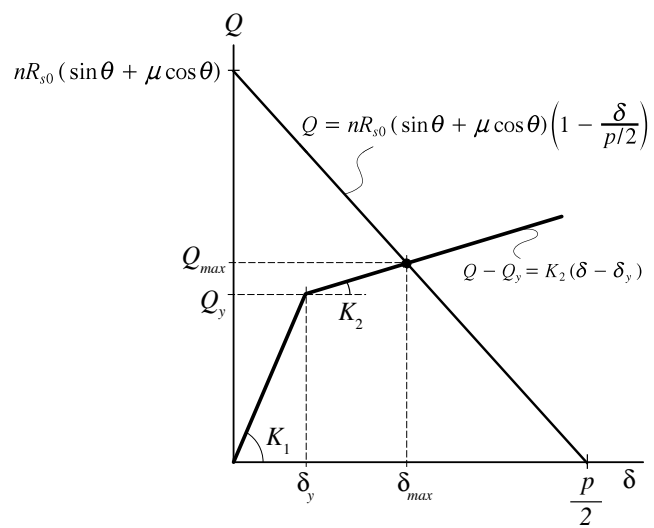

図 10 最大耐力発生時の変形量 $\delta_{\text {max }}$ の求め方

\section{$3.3 \quad k_{b}, k_{s}$ の評価}

3.2 で示した評価では，ボルト座金および山斜面のめり込みに関 する情報を得ておく必要がある。そこで，本節では実験に基づいて ボルト座金のめり込み剛性 $k_{b}$, および山斜面のめり込み剛性 $k_{s}$ の評 価を行う。

まず， $k_{b}$ については， 2 章の 2 面せん断実験および後で比較する モーメント抵抗接合部の実験で用いたものと対応させ，座金の大き さおよび形状の異なる 4 つの試験体に対し図 11 のような載荷装置を 用いた実験を行った。試験体数はいずれの試験体とも 4 体であり, 座金の鋼種はすべて SS400 相当の軟鋼である. 各試験体のめり込み 量と荷重の関係を図 12 に示す。荷重変形関係は，比較的明瞭な降伏 点を持つバイリニア型で表せることから, 目視によって初期岡性 $k_{b 1}$, 降伏荷重 $P_{b y}$, 二次剛性 $k_{b 2}$ を求めた. $k_{b 1}, P_{b y}, k_{b 2}$ の平均值を試験体 寸法とともに表 4 に示す.

次に，山斜面のめり込み剛性 $k_{s}$ の評価について述べる。せん断力 作用時に山の片側斜面は噛み合わせた隣の山斜面から支圧力を受け る。山斜面のすべりが生じていない初期状態では斜面全体が支圧力 を受けるが，山の片側斜面のみがせん断力を伴った支圧力を受ける こと, あるいはすべり変形が進むと噛み合わさった支圧面積が減少 することなどから, 山斜面のめり込みを厳密に評価するのは難しい. そこで, ここでは図 13 に示すように, 山斜面の山頂側 $1 / 2$ (AC 部分) が支圧力を受け，山頂から谷底までの深さ（AE）を持つ長方形部分 （ACDE）が山斜面支圧力により弾性変形すると仮定した。このとき， $k_{s}$ は山斜面支圧力による弾性変形に対するヤング係数 $E$ を用いて, 


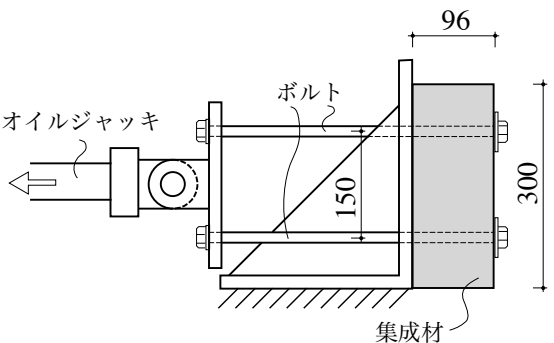

図 11 ボルト座金のめり込み実験

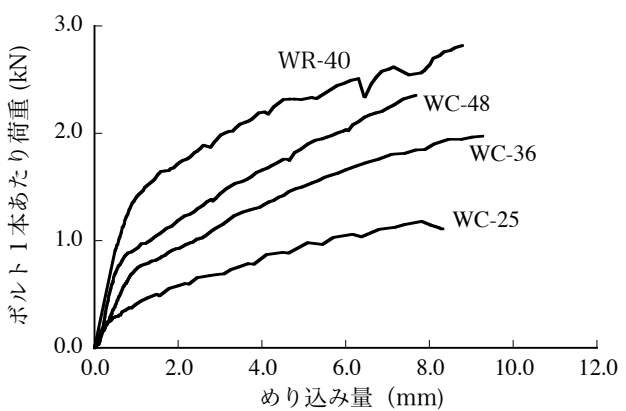

図 12 ボルト座金めり込み実験の荷重変形関係

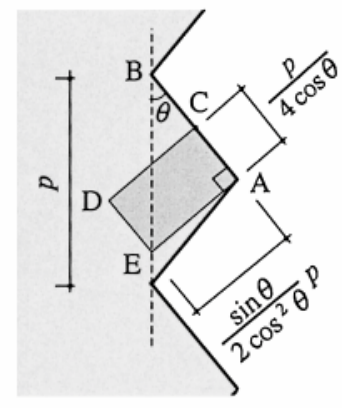

図 13 有効深さの定義

次式で表される。

$$
k_{s}=\frac{E b \cos \theta}{2 \sin \theta}
$$

ここに $b$ ：山の稜線長さである。また， $E$ については，2面せん断試 験体から採取した無欠点小試験体 $(\mathrm{B} \times \mathrm{W} \times \mathrm{H}: 30 \mathrm{~mm} \times 40 \mathrm{~mm} \times$ $60 \mathrm{~mm}$ ）の全面圧縮試験結果（表 5 ）に基づき，山の稜線が繊維方 向の場合には繊維直交方向加力のときの $E$ を，また稜線が繊維直交 方向の場合には便宜的に繊維方向加力のときの $E$ を用いて評価した. なお，山斜面支圧力が繊維直交方向の場合，作用応力の方向が接線 方向か半径方向の特定は困難であることから, 圧縮試験は接線方向, 半径方向, および $45^{\circ}$ 方向の試験体 2 体ずつ計 6 体に対して実施し, その平均值を用いた。 各值を表 5 に示す.

\section{4 力学モデルと実験結果との対応}

本節では， 3.2 で提示した力学モデルに 3.3 の值を適用した場 合の妥当性について検討する．図 14 は（8），(9）および（12）式で 定義した一次剛性 $K_{1}$, せん断耐力 $Q_{y}$ および二次剛性 $K_{2}$ それぞれの 評価値（横軸）と実験值（縦軸）との対応を示したものである， $K_{1}$ (図 14(a)), $Q_{v}$ (図 14(b)）については, 山斜面角度, 山ピッチにかかわ らず，すべての試験体について評価式と良い対応を示した，K（図 14(c)）は全体的には傾向を捉えているが，山斜面角度 $\theta=45^{\circ}$ の試験 体（一，、）において実験值がやや評価值を下回る傾向が見られた。 これは， $\theta=45^{\circ}$ の試験体では降伏荷重 $Q_{y}$ を迎えるやや手前あたりか ら側材が面外曲げ変形を始めたため, 山斜面とボルトのめり込みの みで評価した (12) 式との差が現れたものと考えられる。

次に, 最大耐力時の変形量 $\delta_{\text {max }}$ および最大耐力について検討を行う. (17) 式で $\delta_{\max }$ を評価するにあたっては，せん断面がすべり変形を生 じずに最大耐力を迎えると仮定したときの見かけ上の山斜面反力 $R_{50}$ が必要となる. $R_{s 0}$ は $\delta_{\max }$ と $R_{s}$ の間に反比例の関係があると仮定し, (14) 式で定義した值である。(14) 式を $R_{s}$ について解くと,

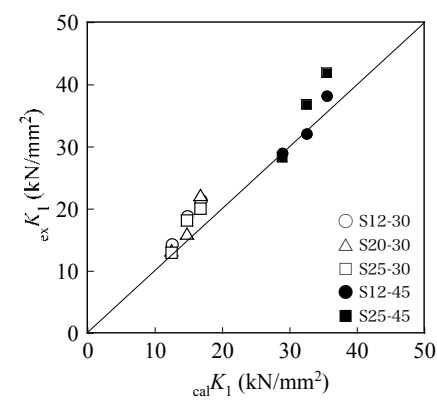

(a) $K_{1}((8)$ 式)

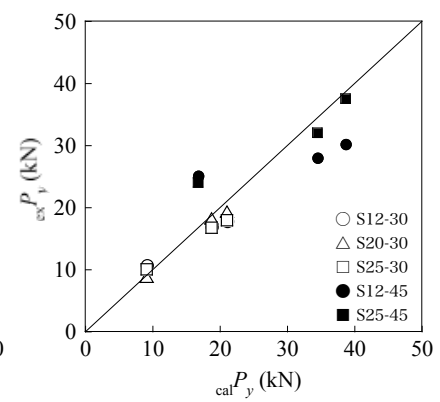

(b) $Q_{y}((9)$ 式)

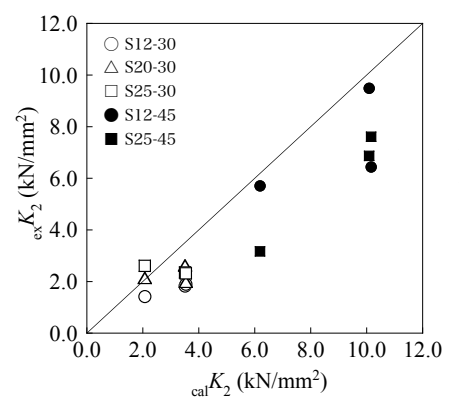

(c) $K_{2}((12)$ 式)
表 4 ボルト座金めり込み実験結果 $(N=4)$

\begin{tabular}{c|c|c|c|c|c|c}
\hline 試験体名 & 座金形状 & $\begin{array}{c}\text { 座金寸法 } \\
(\mathrm{mm})\end{array}$ & $\begin{array}{c}\text { 座金板厚 } \\
(\mathrm{mm})\end{array}$ & $\begin{array}{c}k_{b 1} \\
(\mathrm{kN} / \mathrm{mm})\end{array}$ & $\begin{array}{c}P_{b y} \\
(\mathrm{kN})\end{array}$ & $\begin{array}{c}k_{b 2} \\
(\mathrm{kN} / \mathrm{mm})\end{array}$ \\
\hline WC-25 & 円形 & $25 \phi$ & 2.0 & 10.2 & 3.6 & 1.45 \\
\hline WC-36 & 円形 & $36 \phi$ & 2.0 & 12.5 & 7.4 & 2.51 \\
\hline WC-48 & 円形 & $48 \phi$ & 2.0 & 14.7 & 8.3 & 2.53 \\
\hline WR-40 & 正方形 & $40 \times 40$ & 4.5 & 15.1 & 14.2 & 2.30 \\
\hline
\end{tabular}

表 5 素材圧縮試験結果 $(N=6)$

\begin{tabular}{c|c|c|c|c}
\hline 圧縮加力方向 & $\begin{array}{c}\text { 弾性係数 } \\
E \\
\left(\mathrm{kN} / \mathrm{mm}^{2}\right)\end{array}$ & $\begin{array}{c}\text { 二次弾性係数 } \\
E_{2} \\
\left(\mathrm{kN} / \mathrm{mm}^{2}\right)\end{array}$ & $\begin{array}{c}\text { 降伏ひずみ度 } \\
\varepsilon_{y}\end{array}$ & $\begin{array}{c}\text { 降伏応力度 } \\
\sigma_{y} \\
\left(\mathrm{kN} / \mathrm{mm}^{2}\right)\end{array}$ \\
\hline 繊維方向 & 11.7 & - & 0.0046 & 0.0538 \\
\hline 繊維直交方向 & 0.59 & 0.078 & 0.0061 & 0.0036 \\
\hline
\end{tabular}

$$
R_{s}=-R_{s 0} \frac{\delta_{\max }}{p / 2}+R_{s 0}
$$

となる．図 15 は，2面せん断実験各試験体の $\delta_{\max } /(p / 2)$ と（19）式の $R_{s}$ の関係をプロットしたものである. (14) 式の仮定通り $\delta_{\text {max }}$ と $R_{s}$ に は反比例の傾向が見られ，(19) 式から縦軸の切片が $R_{50}$ に対応するこ とから本実験における $R_{50}$ は山斜面角度 $\theta=30^{\circ}$ の試験体では $0.01 \mathrm{kN}$, $\theta=45^{\circ}$ の試験体では $0.006 \mathrm{kN}$ と設定した。図 16 は図 15 で定量化し た $R_{s 0}$ を用い，(17) 式および (13) 式で求めた $\delta_{\text {max }}$ と $Q_{\text {max }}$ の評価精度 を示したものである。いずれの試験体でも高い精度で実験結果を説 明できているといえる.

\section{4.モーメント抵抗接合部の剛性および耐力評価}

\section{1 パネルゾーンを分割した接合部の耐力評価方法}

前章までで示した山形接合面のせん断剛性および耐力の評価方法 を応用し，本章ではモーメント抵抗接合部の耐力の評価を行う.

図 14 初期剛性，降伏強度，二次剛性の評価精度

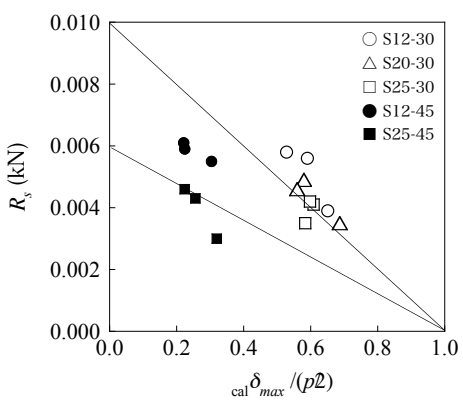

図 $15 R_{s 0}$ の評価 
モーメント抵抗接合部の評価にあたつては，まず図 17 に示すよう に接合部パネルゾーンを $N$ 個の正方形の領域（以下セルと呼ぶ）に 分割する. 次に図 18 に示すように接合部の中心にモーメントが作用 したとき, 接合部は $\phi$ 回転し $i$ 番目のセルの中心が $\delta$ 移動したとする. このときの移動前後のセルの関係は, 山稜線方向から $\phi_{i}$ の方向で距 離 $d_{i}$ のセルを例に示すと図 19 のようになり, このセルが負担する作 用モーメント $M_{i}(\phi)$ は次式となる.

$$
M_{i}(\phi)=Q_{i}(\phi) d_{i} \cos \left(\phi_{i}+\phi\right)
$$

ここに $Q_{i}(\phi)$ は接合部が $\phi$ 回転したときに $i$ 番目のセルに作用する山 の稜線直交方向の反力である。最終的に, 接合部が $\phi$ 回転したとき の接合部の作用モーメント $M(\phi)$ は, 各セルの負担モーメント $M_{i}(\phi)$ をモーメントを負担していると考えられる全セルについて足し合わ せることで次式のように求められる.

$$
M(\phi)=\sum_{i=1}^{n} M_{i}(\phi)
$$

\section{2 各セルの荷重変形関係の評価}

前節での評価では, 各セルに対する $Q_{i}(\phi)$ が必要である．接合部 の回転角 $\phi$ が決まれば任意のセルのせん断変形量が決まることから, $Q_{i}(\phi)$ を求めるには各セルに対して 3 章で述べた剛性 $K_{1}$ と $K_{2}$, 耐力 $Q_{y}, Q_{\max }$ を用いることができる，ただし，モーメント抵抗接合部の 挙動に応用するためには, 2 面せん断挙動では考慮していなかった 次の 2 点を考慮に入れる必要がある.

1 ）パネルゾーンが剛体変形をすると仮定すると，回転中心から離 れたセルほどせん断変形量が大きい. 山形接合部のせん断変形は 側材の開きを伴うため, 回転中心から遠い位置の側材が開くと回 転中心に近い位置では側材と主材が離間し, 応力伝達能力を失う.

2 ）ボルトから離れた位置のセルは側材の面外曲げ変形の影響で見 かけ上のボルト座金のめり込み剛性 $k_{b 1}, k_{b 2}$ が低下する.

1 ）については, 山形接合面の応力伝達が主に山斜面を介して行 われることを考慮し, 図 20 に示すように分割したセルのうち山稜線 方向最外縁のセル（網掛け部分のセル）のみが応力を伝達する有効 セルと仮定した。 また，2）については，同じく図 20 に示すように ボルト配置円からの側材の跳ね出し部分をスパン $l$ の片持ちばりと見 なし，その片持ちばり部分の面外曲げ剛性 $k_{c}$ を考慮して側材の開き に対する $i$ 番セル用のボルトの剛性 $k_{b 1(i)}, k_{b 2(i)}$ を次式により求めた.

$$
k_{b 1(i)}=\alpha \beta_{i} \frac{N_{b} k_{b 1}}{N_{e}}, \quad k_{b 2(i)}=\alpha \beta_{i} \frac{N_{b} k_{b 2}}{N_{e}}
$$

ここに, $\alpha$ : 有効セルとボルトの距離に応じたボルト剛性の低減係数, $\beta_{i}: i$ 番目のセルの応力分担割合であり, それぞれ次式で算出する.

$$
\begin{aligned}
& \alpha=\frac{k_{c}}{k_{c}+N_{b} k_{b 1}} \\
& \beta_{i}=\frac{e_{i}^{3}}{\sum_{j=1}^{N_{e}} e_{j}^{3}}
\end{aligned}
$$

ここに,

$$
k_{c}=\frac{E a t_{a}^{3}}{4 l^{3}}
$$

であり, $N_{b}$ : ボルト本数, $N_{e}$ : 有効セル数, $e_{i}: i$ 番目のセルの中心 とボルト配置円との距離 (図 20 参照), $E$ : 側材の曲げヤング係数, $a$ : 側材の幅, $t_{a}$ : 側材の平均厚さである. セルの $y$ 方向変位 $\delta_{i y}$ と $\phi$ との関係は,

$$
\delta_{i y}=\delta_{i} \cos \left(\phi_{i}+\phi\right)=d_{i} \phi \cos \left(\phi_{i}+\phi\right)
$$

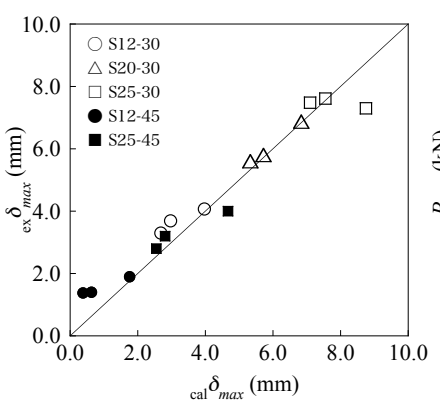

(a) $\delta_{\max }((17)$ 式)

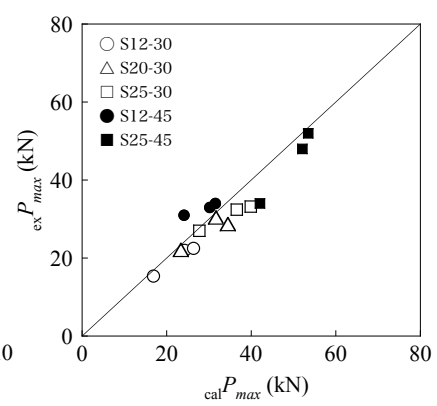

(b) $Q_{\max }((13)$ 式)
図 16 最大耐力時変形量と最大耐力の評価精度
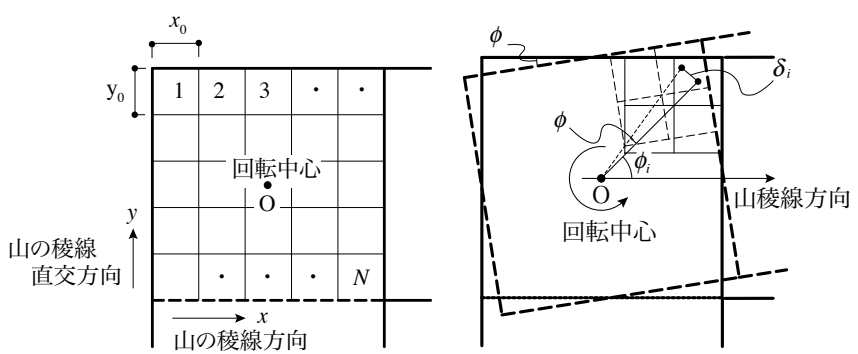

図 17 パネルゾーン内のセル分割

図 18 パネルゾーンの回転

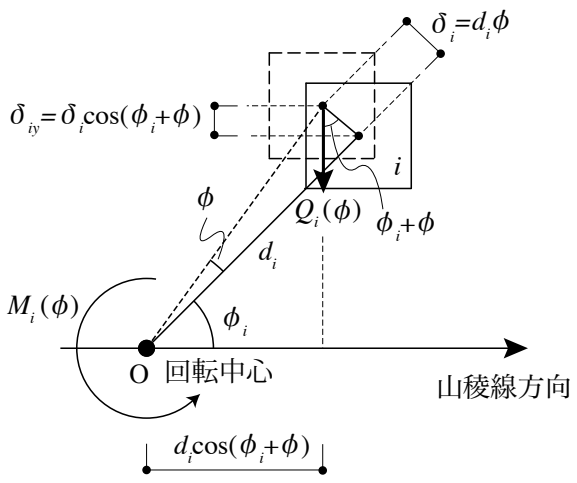

図 19 セルの回転変形に伴う $x, y$ 方向変位と $\phi$ の関係

で表されることから，上式で求めた $\delta_{i v}$ と，（8）式の初期剛性 $\left.K_{1}, （ 9\right)$ 式の降伏耐力 $Q_{v}, （ 12 ）$ 式の二次剛性 $K_{2}$, （13）式の最大耐力 $Q_{m a r}$, および（17）式の最大耐力時の変形量 $\delta_{\text {max }}$ に（22）式の $k_{b 1(i)}, k_{b 2(i)}$ を $k_{b 1}, k_{b 2}$ の代わりに適用して表わされる $i$ 番セルの荷重変形関係を使 えば（20）式中の $Q_{i}(\phi)$ を評価することができ，それを（21）式に用 いることで接合部の回転角と作用モーメントの関係を得ることがで きる。

\section{3 モーメント抵抗接合部実験結果との対応}

前節までで述べたモーメント抵抗接合部の荷重変形関係の評価方 法と実験值との対応から妥当性の検証を行う。対象とする実験結果 は，既報 ${ }^{5)}$ で報告している試験体のうち，表 6 に示す 6 体を対象と した．試験体の山形状はいずれも $p=25 \mathrm{~mm}, \theta=45^{\circ}$ である. A シ リーズ試験体は主材，側材ともに $250 \mathrm{~mm} \times 50 \mathrm{~mm}$ の断面を有す るモーメント抵抗接合部であり，パネルゾーンは $50 \mathrm{~mm}$ サイズの セル 25 個に分割して評価した。また，B シリーズ試験体は主材が $550 \mathrm{~mm} \times 96 \mathrm{~mm} ，$ 側材が $550 \mathrm{~mm} \times 48 \mathrm{~mm}$ の断面を有する接合部 であり，パネルゾーンは $\mathrm{A}$ シリーズと同じ大きさの $50 \mathrm{~mm}$ サイズの 
セル 121 個に分割して評価した. 同表には, 有効セル数 $N_{e}$, 式 (23) の $\alpha$ の評価に必要な片持ちばりスパン $l$, およびの $\alpha$ の值も併記した. また, 試験体 A-S6 を例に, 各セルの荷重変形関係評価に必要な（24） 式の係数 $\beta_{i}$ および，各有効セルの荷重変形関係を図 20 中に示した.

ところで，前節までの評価は山斜面の抵抗のみに関するものであ るため，実験結果と対応させるためには山形加工のないボルトのみ の接合部挙動と合算する必要がある。そこで，既報 ${ }^{5)} て ゙$ 比較用に用 いられているボルトのみの接合部の荷重変形関係を図 21 に示す直線 で近似し，これと（21）式の評価值とを足しあわせて実験結果と比 較した。

図 22 はこうして得られた荷重変形関係とモーメント抵抗接合部の 実験結果との対応を示したものである．最大耐力以降の挙動でやや 誤差が認められるものの，全体的には初期剛性，降伏点，最大耐力 点ともに実験結果をよく説明できていると言える.

\section{5. 結論}

本研究で得られた結論は，下記の通りである。

1 ) 山形接合部のせん断挙動に対し，側材を締め付けるボルト座金 のめり込み，接触する山斜面の支圧および摩擦を考慮した力学モ デルを提案した。

2 ) 山形接合部の 2 面せん断実験を行い, 提案した力学モデルの妥 当性を検証した。 その結果として, 初期剛性, 降伏耐力, 二次剛性, 最大耐力, 最大耐力時の変形はそれぞれ（8)，(9)，(12)，(13)，(17) 式で評価できることを示した。

3） 2 面せん断挙動の評価結果をモーメント抵抗接合部の挙動に応 用し，モーメント抵抗接合部の荷重変形関係の評価方法を提示す るとともに，既往の実験結果との対応からその妥当性を示した。

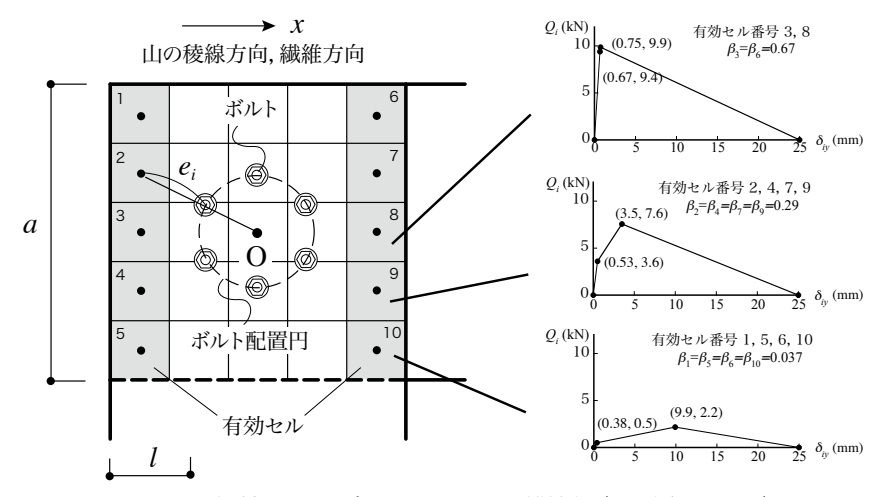

図 20 有効セルと各セルの $\delta_{i v}-Q$ 関係（試験体 A-S6）

表 6 検証のためのモーメント抵抗接合部試験体概要 ${ }^{5)}$

\begin{tabular}{|c|c|c|c|c|c|c|c|c|c|}
\hline 試験体名 & $\begin{array}{l}\text { ボルト } \\
\text { 本数 }\end{array}$ & $\begin{array}{l}\text { ボルト } \\
\text { 種類 }\end{array}$ & $\begin{array}{c}\text { ボルト配置 } \\
\text { 円の半径 } \\
(\mathrm{mm})\end{array}$ & $\begin{array}{c}\text { パネルゾーン } \\
\text { サイズ } \\
(\mathrm{mm}) \\
\end{array}$ & $\begin{array}{r}\text { 側材厚 } \\
(\mathrm{mm})\end{array}$ & 七ル分割数 $\mid$ & 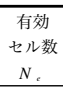 & $\begin{array}{c}\text { 片持梁スパン } \\
l \\
(\mathrm{~mm})\end{array}$ & $\alpha$ \\
\hline A-S1 & 1 & \multirow{3}{*}{$\begin{array}{c}\text { M12 } \\
\text { WC-25 }\end{array}$} & 0 & \multirow{3}{*}{$250 \times 250$} & \multirow{3}{*}{50} & \multirow{3}{*}{$5 \times 5$} & \multirow{3}{*}{10} & 125 & 0.87 \\
\hline A-S4 & 4 & & 41 & & & & & 84 & 0.85 \\
\hline A-S6 & 6 & & 82 & & & & & 43 & 0.97 \\
\hline B-S1 & 1 & \multirow{3}{*}{$\begin{array}{c}\text { M12 } \\
\text { WR-40 }\end{array}$} & 0 & \multirow{3}{*}{$550 \times 550$} & \multirow{3}{*}{48} & \multirow{3}{*}{$11 \times 11$} & \multirow{3}{*}{22} & 275 & 0.49 \\
\hline B-S9 & 9 & & 215 & & & & & 60 & 0.91 \\
\hline B-S25 & 25 & & $130 \& 215$ & & & & & 60 & 0.79 \\
\hline
\end{tabular}

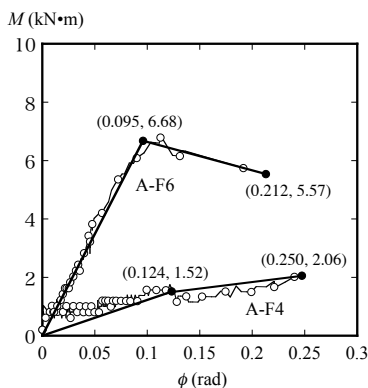

(a) A シリーズ試験体

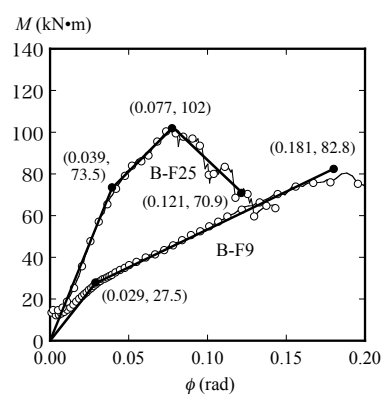

(b) B シリーズ試験体

図 21 山形加工無しの試験体の荷重変形関係 ${ }^{5)}$

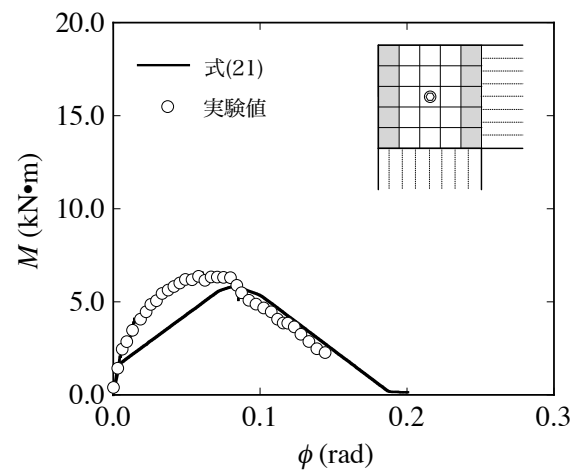

(a) 試験体 A-S1

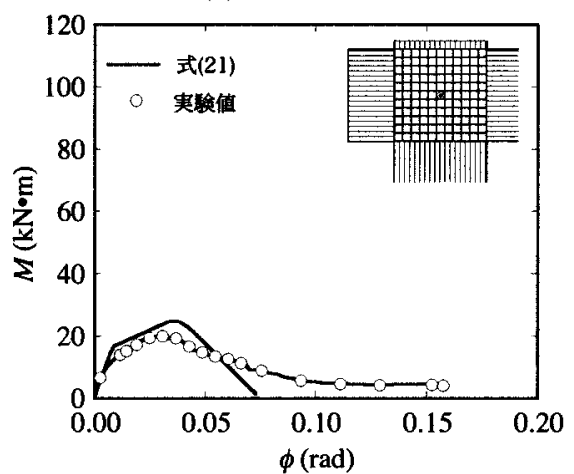

(d) 試験体 B-S1

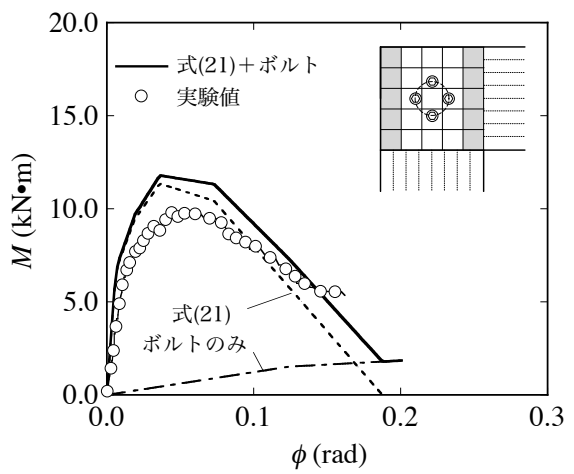

(b) 試験体 A-S4

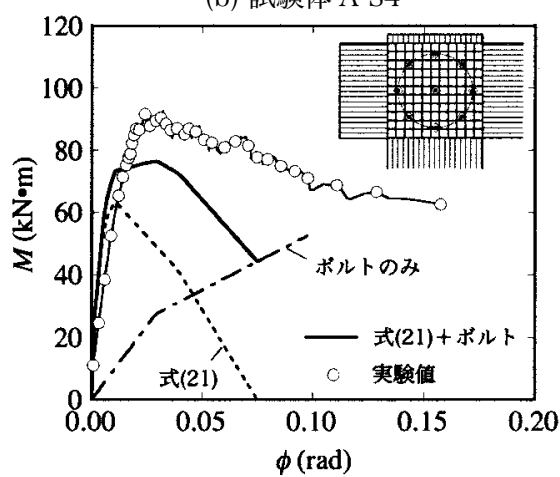

(e) 試験体 B-S9

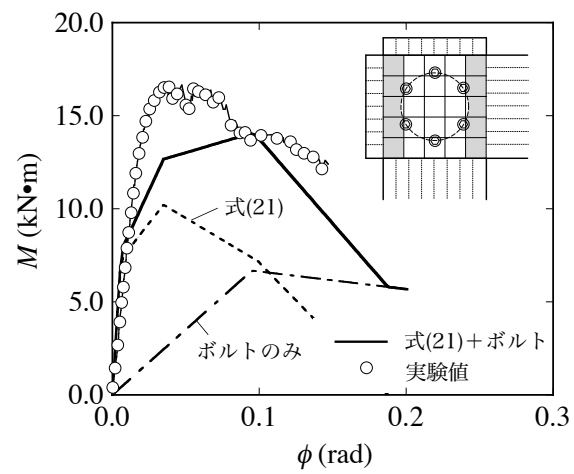

(c) 試験体 A-S6

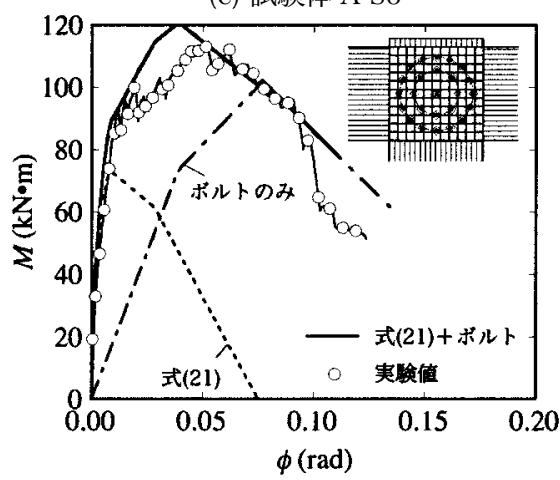

(f) 試験体 B-S25

図 222 面せん断実験結果から評価したモーメント抵抗接合部の荷重変形関係と実験值 ${ }^{5)}$ との対応 
本報で提示した評価は今回の研究で対象とした試験体に限られた ものである. 今後, 本モーメント抵抗接合部の実用化にあたっては, さらに山形状や樹種の影響等，一般性を持った評価を行っていく必 要がある.

\section{謝辞}

実験の実施，および実験デー夕の整理にあたっては，(有) ケーイ ングの塚本泰久氏，（株）JR 東海建設の岡田 真氏，および大成建 設（株）の嶺岡慎悟氏の協力を得ました。また，本研究の実験の一 部は, 耐震実験施設の効率的運用による東海地域の地震災害軽減連 携融合事業（Task 4 : 耐震補強効果実証実験）による研究推進等経 費によりました。ここに感謝の意を表します。

\section{参考文献}

1) 岡田 真, 井戸田秀樹, 塚本泰久 : 接合面に山形加工を施した集成材モー
メント抵抗接合部の提案，その 2 山形加工接合部の剛性および耐力評 価, 日本建築学会東海支部研究報告集, 第 42 号, pp.293-296, 2004.2

2 ) 岡田 真, 井戸田秀樹 : 接合面に山形加工を施した集成材モーメント抵抗 接合部の提案，その 2 山形加工接合部の剛性および耐力評価，日本建築 学会大会学術講演梗概集，構造 III，pp.333-334，2004.8

3 ) 嶺岡慎悟, 井戸田秀樹 : 接合面に山形加工を施した集成材モーメント抵抗 接合部の提案, その 3 モーメント抵抗接合部の耐力評価, 日本建築学会 東海支部研究報告集，第 43 号，pp.197-200，2005.2

4) 嶺岡慎悟, 井戸田秀樹 : 接合面に山形加工を施した集成材モーメント抵抗 接合部の提案, その 3 モーメント抵抗接合部の耐力評価, 日本建築学会 大会学術講演梗概集，構造 III，pp.197-2000，2005.9

5 ) 井戸田秀樹 : 接合面に山形加工を施した集成材モーメント抵抗接合部の提 案，日本建築学会構造系論文集，第 598 号，pp. 117-123，2005.12.

6) 軸組工法木造住宅の許容応力度設計, 日本住宅木材技術センター

（2007年10月10日原稿受理，2008年 2 月14日採用決定） 